\title{
Comparative study of India's organic agriculture with the LeadingCountries: Europe and U.S.A
}

\author{
KritikaGurung, Prerna Sharma and MandeepDhalor \\ Panjab University department of environmental scienceChandigarh 160014
}

\begin{abstract}
India is one of the fastest growing among the developing countries with its high GDP and is also emerging as a good competitor in the field of organic market due to some of its exclusive product (cotton \& spice). India is ranked number one in the highest producer worldwide and has some added advantage in organic agriculture, as the concept was already in practice many years ago until green revolution and still few parts of country has been following the traditional method now termed as "organic by default". Despite of these pluses the organic agriculture is still growing at very slow pace. My paper deals with the comparative analysis of the India and the other leading countries Europe and USA, the study of their strategies, policies and their way of conduct in the field of organic agriculture enabling us to understand the present Indian agriculture system its potential, opportunity and challenges and its possible solution.

Key words: organic agriculture, global scenario, Europe, U.S.A, policies.
\end{abstract}

\section{Introduction}

What exactlyis organic agriculture? Is it the use of traditional farming practises instead conventional farming, using sustainable methods, jaivikkrishi etc.? Most of us think that the use of organic manures like green manure or natural plant protection by not using chemical fertilizers or pesticides is organic agriculture but this is not true the real meaning of the organic agriculture is just not confined to the word "agriculture" it has got much broader characteristics and impression capturing most of the biological and ecological aspects

The target of the organic agriculture is the soil and not the plant specifically. It believes at creating a strong foundation for the overlying spread so that the nourishment is provided through the natural biological process(crop rotation, crop residues, animal manure, planting with legumes, green manure, off farming organic) and not through the man-made supplements

The whole organic agriculture is based on a very meticulous system where every organism involved inside is interdependent on each other for their own existence, creates balance in ecological cycle and lays down the substance for the sustainable growth. The most recognised definition of the organic agriculture is given below

"The term "organic" is best thought of as referring not to the type of inputs used, but to the concept of the farm as an organism, in which all the components -the soil minerals, organic matter, microorganisms, insects, plants, animal and humans - interact to create coherent, self-regulating and stable whole. Reliance on external inputs, whether chemical or organic, is reduced as far as possible. Organic farming is holistic production system" (p. Bhattacharyyaand g. chakraborty)

Organic agriculture proposes a huge commerce and trade opportunities in both developed and developing countries due to high demand of the organic product in market, its sustainable agriculture approach and also due to theirsalientsupport provided by the government and organization like the European Union and international federation of organic Agriculture Movements (IFOAM).Developed countries are already at power to developing countries in organic sector due to their strong policy and strategies have established a stable market for them. Organisation like NGO's and government bodies plays a very significant role in the development of organic agriculture in developing countries.

India is one of the developing countries young in this organic market this paper deals with the comparative study of the India and other developed countries and there methodology used in the improvement and proper regulation in their organic agriculture practises with a prospective to wider the vision of Indian organic agricultureleading to better understanding of current situation requirements and help in building appropriate stratagems.

\section{Global scenario}

\section{Methodology}

Worlds total agriculture land account for 37.2million hectare land. Australia leads the chart with 12 million hectare land followed by Argentina4.40million hectare and then USA 1.95 million hectare (Fig-1). 
Global sales of organic product food and beverages had touched 59billion dollar by 2010 (AmarjitSahota, page 122)a remarkable increase was seen throughout the years. The market has extended three times from 17.9 billion US dollar (2000) in last 10 years.(Fig- 2) Though in 2008 global market was hit by financial crisis all over but organic sales market did not stop, it did go slow but kept increasing at a fair rate.

Organic product is concentrated specifically in North America and Europe which comprises 96percent of global revenue. Countries holding the top position in organic market are USA, Germany and France. Australia, Argentina being the largest land holders under organicis behind in the race of the organic market compared to other leading countries, due to thedifference in the production and consumption patterns governed by consumer behaviour hence consumerism playsan eminent role in the growth of the market.

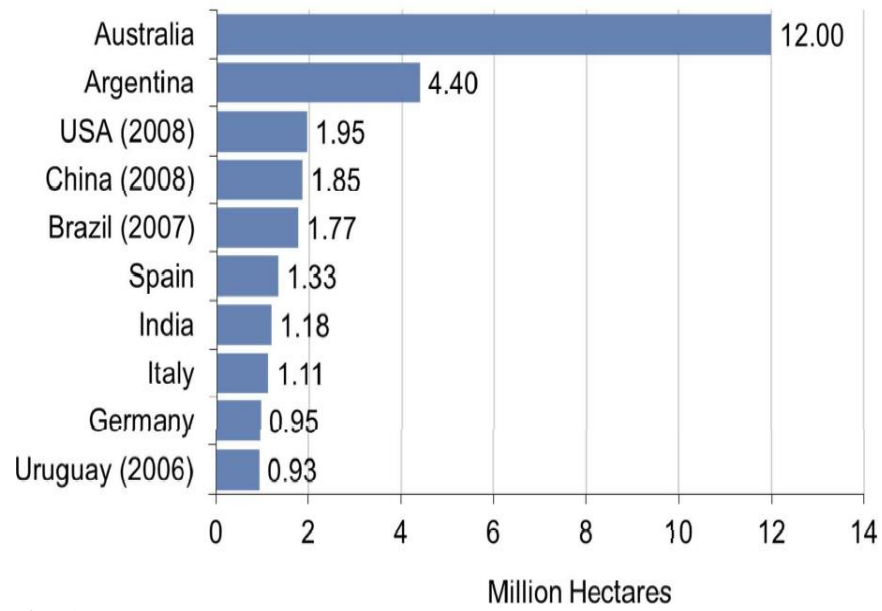

Fig 1: Top ten countries with most agriculture land on global scale

Among the total organic land two third is the grassland or grazing land of about 23.7 million hectare of land and arable land constitute about 6.1 million hectare of land which is approx. 17percent of the total organic agriculture land. There were 1.6 million total producers in 2010, Africa shared 34percent, Asia 29percent and Europe18percent and India lead the league with (400'551) figure followed by Uganda (188'625) then Mexico(128'862) (Helga willer 2012). World's largest producers are present in developing countries

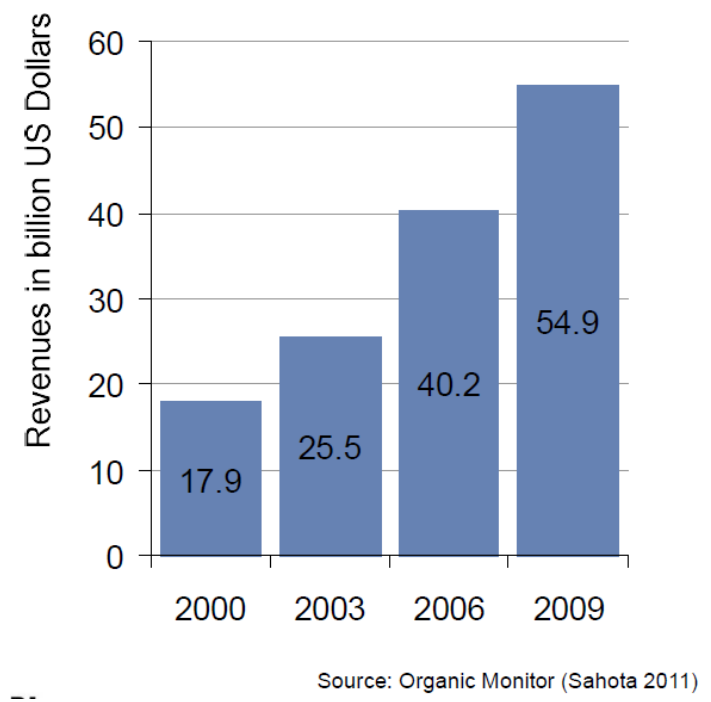

Fig 2: global food and beverages market

Source: FiBle survey 2009

\section{EUROPE}

Europe take up the 28percent of the total organic agriculture of land, according to the statistics of 2010 Europe comprise of 2.1percent of agriculture area and the European union has5.1percent of the land, there was an increase of 0.8 million hectare land from 2009..About 10 million hectare of organic land is managed by the $280^{\prime} 000$ farms.Countrys with largest land area are Spain (1.5 million hectare),Italy(1.1million hectare), 
Germany $(0.99$ million hectare) and there are about 10 country's with more than 10percent share of the land.Sales in organicproduct in the Europe touched 19.6 billion euros in 2010, Germany topes the market chart with 6 billion euros followed by France 3.4 billion euros and then UK with 2billion euros.(Fig-3)

There is 45 percent of the arable land crops, 45 percent of permanent grassland, permanent crops takes up the 10percent of the land, 3\% are taken up by other agriculture land and the key permanent crops are olives, grapes,nuts, etc. Arable crop grown are cereal, green fodders, protein crops etc.

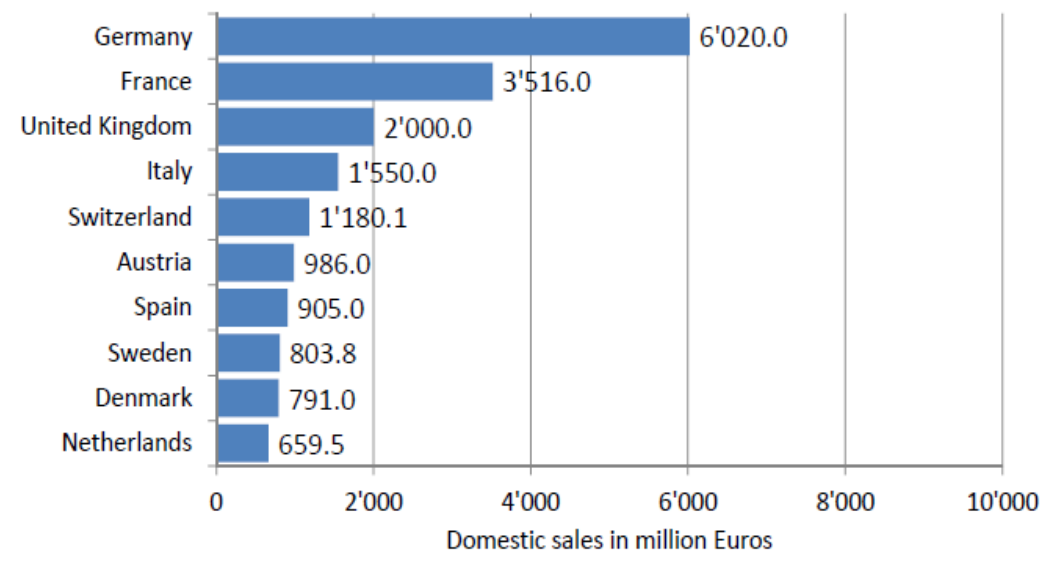

Fig 3: The European market for the food and DrinkSource: FiBLE survey 2012

\section{Organic regulatory system}

There are three mainpillars when it comes to the regulation of the organic environment it act as an key instrument in the processing and monitoring of the organic agriculture they are legal instrument, financial instrument and communicative instrument (Michelson, 2002).

\section{Legal instrument}

Legal instrument is based on the authority and power of the statesever since 1993 organic production, labelling and certifications are legally formulated under (EEC)NO2092/9. This regulation has worked as base for many non EU states like Switzerland, Norway and has inspired many countries too like America, Canada and has stimulated the existence of guidelines for organic farmingunder FAO and WHOCodex.Another Council regulation (EC) no.1804/1999ofjuly99 supplementingregulation (EEC) no 2092/91 on Organic production of agricultural products was formed included live stocks too

Every certified organic product should have label on it as described by the European government .Original guidelines are always put through revision so that the core meaning of organic farming principles are not lost ,disciplines are maintained and statistic of various field are analysed timely and newimprovised rules are passed under commission regulation (EEC)NO889/2008.

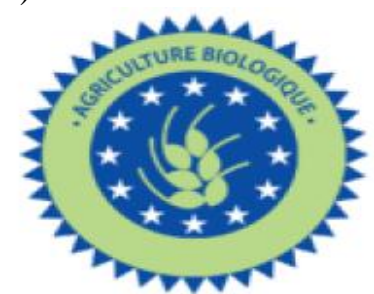

European Union

\section{The financial instrument}

It deals with the price mechanism positive in terms of support and negative in forms of taxes or duties. Many states provide financial support during the conversion period of three years, states like Bulgaria and Romania has introduce the financial support as a part of guideline (2007-2013)and in 2005 EU had already made the financial support as the major part under rural and development accounted EU25. All the EU member state support schemes for organicConversion and maintenance pinned under the same EU regulations (1698/2005 for 2007-2013, 1257/1999 for 2000-2006, 2078/92 for 1994-1999),there is always variation in the funding system country to country depending upon the payment rates, eligibility conditions and requirements.( Matthias Stolze a, ${ }^{*}$, Nicolas Lampkin b) 


\section{Communicativeinstrument}

This instrumentis based on the programs involved to bring about interaction between the regulator and the regulated citizens to bind all and create awareness in both the parties; it specially targets the zone of information, communication and research, and training and advice to both the sides. In 2004, 15 states funded training and education program for organic farming which was related to create cognizance in relation to organic farming this effort lead to the formation of National Funded Organics Extension and advice in all the European Union in 2006. During that year only a promotional campaign for organic food was launched ,65 organic research projects were funded under $1^{\text {st }}$ and $6^{\text {th }}$ framework project and now almost all states provides national financial support in organic farming(Matthias Stolze a, ${ }^{*}$, Nicolas Lampkin b)

European Commission launched the European Action Plan for Organic Food and Farming in 2004which was the result of the three year developing process started in 2001 focused primarilyon giving consumer information and promotion, improved research and marketing intelligence and collection of statistical data and utilise the rural and Improving the transparency, scope and implementation of the regulation defining organic farming (figure 4)

\begin{tabular}{|c|c|c|c|}
\hline Country & Name of Action Plan & $\begin{array}{l}\text { Running from } \cdot \text { to } \\
\text { Total funding }\end{array}$ & Quantitative targets \\
\hline Austria & $\begin{array}{l}\text { Action plan organic agriculture 2008-2010' } \\
\text { Aktionsprogramm Biologische Landwirtschaft 2008- } \\
2010\end{array}$ & $\begin{array}{l}\text { 2008-2010 } \\
\text { Previous action plan: } \\
\text { 2005-2008 }\end{array}$ & $20 \%$ organic land area by 2010 \\
\hline Belgium - Flemish part & $\begin{array}{l}\text { Flemish Action plan for organic farming 2008-2012 } \\
\text { Strategisch Plan Biologische Landbouw 2008-2012² }\end{array}$ & 2008-2012 & No quantitative targets \\
\hline Bulgaria & $\begin{array}{l}\text { National Plan for Development of Organic Farming } \\
\text { in Bulgaria 2007-2013 }\end{array}$ & $2007-2013$ & $8 \%$ organic land area by 2013 \\
\hline Czech Republic & $\begin{array}{l}\text { Action Plan of the Czech Republic for the } \\
\text { development of organic farming until } 2010^{4}\end{array}$ & until 2010 & $10 \%$ organic land area by 2010 \\
\hline
\end{tabular}

\begin{tabular}{|c|c|c|c|}
\hline Country & Name of Action Plan & $\begin{array}{l}\text { Running from - to } \\
\text { Total funding }\end{array}$ & Quantitative targets \\
\hline Denmark & Action plan II Development in organic farming ${ }^{5}$ & $1999-2003$ & $12 \%$ organic land area by 2003 \\
\hline Estonia & Estonian Organic Farming Action Plan 2007-2013 & $2007-2013$ & \\
\hline France & $\begin{array}{l}\text { Organic agriculture until 2012: New measures to } \\
\text { triple the organic surface } \\
\text { Agriculture biologique : Horizon 2012": De nouvelles } \\
\text { mesures pour tripler les surfaces }\end{array}$ & $2008-2012$ & $\begin{array}{l}6 \% \text { organic land by } 2012 \\
20 \% \text { organic products in } \\
\text { government canteens by } 2012\end{array}$ \\
\hline Germany & Federal Organic Farming Scheme & $\begin{array}{l}\text { Phase } 12001-2008 \\
\text { Phase 2: } 2008 \text { - } 2015\end{array}$ & $\begin{array}{l}20 \% \text { organic land area , but no } \\
\text { target year }\end{array}$ \\
\hline Ireland & The Organic Farming Action Plan 2008-2012 ${ }^{8}$ & $2008-2012$ & $5 \%$ organic land area by 2012 \\
\hline Italy & $\begin{array}{l}\text { Italian National Action Plan for organic agriculture } \\
\text { and organic products (Piano d'Azione nazionale per } \\
\text { I'Agricoltura Biologica e i Prodotti Biologici) } \\
\text { April } 2005\end{array}$ & $\begin{array}{l}2005 \text { with follow-up measures in the } \\
\text { subsequent years } \\
5 \text { million Euros } 2005\end{array}$ & No quantitative target \\
\hline Latvia & $\begin{array}{l}\text { An Organic action plan development programme } \\
2007-2013 \text { has been elaborated by the Latvian } \\
\text { Association of Organic Agriculture, not yet officially } \\
\text { approved by the government }\end{array}$ & & \\
\hline
\end{tabular}

Fig 4: Organic action plan compilation of result of EU

(Source: ORGAP Project newsletter No. 6 at http://www.orgap.org/documents/newsletter/orgap-newsletter-6july2008.pdf with updates.) 


\section{UNITED STATES OF AMERICA}

The North America consist of two main countries firstly United States of America and Canada US has around 1'94'946 million hectare land under organic agriculture which is approximately 73percent and Canada share is 27percent i.e. 703'678(SOEL Survey 2010).USA leads the organic market .Organic food sales in US in 2006 was about 17'221 an then 8percent growth was seen in the U.Smarket in 2010 and reached to 28-29 billion us dollars (food and non-food)(figure 5) (Matthias Stolze a, ${ }^{*}$, Nicolas Lampkin b).

\section{Development of the US Organic market}

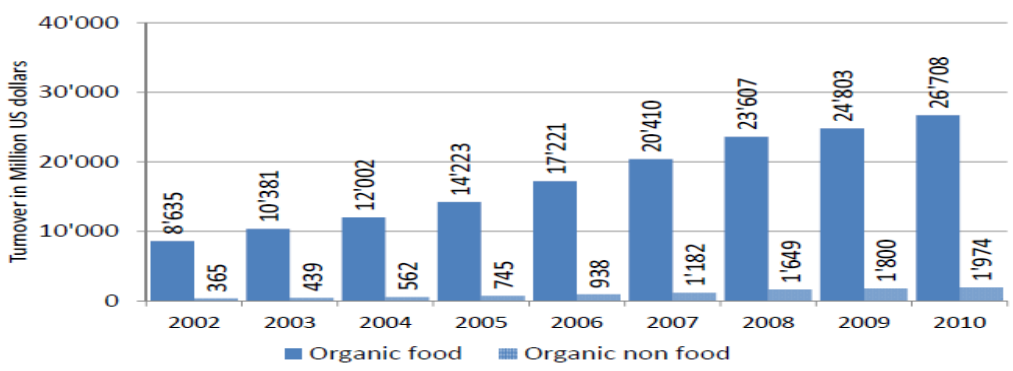

source:FiBLE survey 2012

Figure 5: Development of the US organic market

Year 2005 is marked as a national achievement as in this year all the 50 states of US had some certified organic farmland. The distribution of the pattern in USA is divided into three broad category "natural food stores" holds $44 \%$ of the total sale of the organic products then "conventional retailer" with $38 \%$ and "other market" ( farmers direct market, mass merchandise and club, stores, restaurant, exports and other marketing channels).

\section{Regulation}

In 1990 two main bodies were formed by OFPA which geared the progress in organic faming

1. Agricultural Marketing Service (AMS) under United States department of agriculture (USDA)

2. National Organic Standard Board (NOSB)

AMS-keeps the track of the trading going on in agriculture does inspection of the certifying bodies in every 5 years and has the authority to cancel the producer certification or the certifying agent if found guilty.

NOSB- it consisted of 15 members, all expertise in their fields were to focus on the expansion of standards for the substance to be used in organic production (referred as national list) and also to provide recommendations regarding enactment main objectives of NOSB are listed below

1. Standards for the production and handling including a national list of the substances that can be used and cannot be used

2. National level accreditation certifying agents for the state and private organizations strictly under USDA national standards for organic certifiers

3. Organic label and organic ingredient to be mentioned on the product

4. civil penalties in case of violation of regulation

(U.S. Organic Farming in 2000-2001by Catherine)

Under NOSB any producers or handler who wants to market their product as organic had to strictly abide by the guidelines given in the regulation an annual inspection is done by USDA accredits (private or state certification agents) and after the satisfactory tenure of conversion period (3 years) certification is given.

USDA is very particular about labelling "organic", it's illegal to use word "organic" if the product is not according the standards. Product with label "organic' signifies that the product is $95 \%$ or more organic and with label "made with organic" means $75 \%$ to $95 \%$ organic and will not carry seal on it. US only imports products from the countries which have got accreditation from the USDA-accredited certification agents. If a state wants to add to the standards then it has to first get verified and approve by USDA, private organisations are also allowed to put their own label in addition to the USDA label which would only mean that the standards formed by the private organisation is only in addition to USDA but not at power to the national standards. 


\section{US organic policy}

1. USDA implemented a national organic program in 2002, which set uniform standards and provided a "USDA-organic" label to facilitate market transactions and allay consumer concerns about product identity.

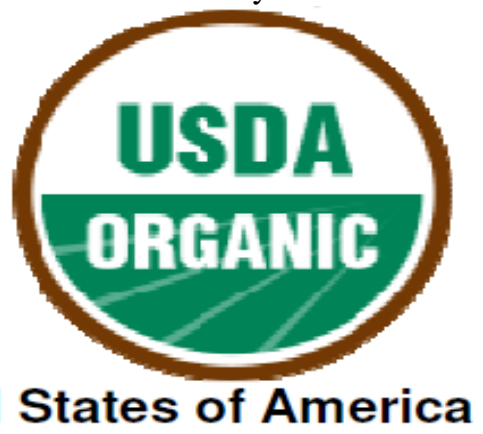

2. USDA's Agricultural Marketing Service currently administers two organic certification cost-share programs. The first offers assistance to producers in 15 States and operates with $\$ 1.0$ million annually as part of the Agricultural Management Assistance (AMA) program under the Federal Crop Insurance Act. The second program expanded assistance to all U.S. farmers and handlers under the 2002 Farm Act, with one-time funding of $\$ 5.0$ million that has already been obligated to participating States.

3.In 2003, the National Association of State Departments of Agriculture (NASDA) released a policy statement on organic agriculture expressing support for a wide range of activities that would expand public-sector organic research and education and provide technical assistance to organic and transitional farmers

5. In 2006 National Organic Action plan (NAOP) came into existence initiated by the Rural Advancement Foundation International and leads the NAOP. The blueprint of it was based on three factors support family farmers, protect human health and benefit the environment

(Source: united States agriculture department)

\section{INDIA}

India the land of 21 agro-ecological zones already has an added advantage in agriculture due to its different geography in climate and soil pattern facilitating the production of different variety of crops which is definitely a plus point from the point of view of diversity in organic product and market. Other additional advantages for going into organic in India are:

1. Certain area referred as "organic by default" like mountains, north east areas as they already used traditional agriculture practises for years and have proved to be very good in production of crops as compared to the conventional farming

2. India already holds a very strong position in the market for the quality of certain production like tea, spices, rice specialities and herbs so it does act as an additional credit in international market.

3. Cost of labour is relatively cheap than the cost of input, in organic farming farmer is independent of the input cost but is of more labour intensive system

Total producer statistic of Asia is 0.5 , India share is 0.4 million producer and china with 0.1 million (Helga willer2012). This makes India world number one in the largest producer, stands at $33^{\text {rd }}$ position in area under organic farming and $88^{\text {th }}$ inthe ratio of agricultural land under organic crop to total farming area.

The National Program for Organic Production (NPOP) was implemented by agricultural and processed food products export development authority (APEDA), the job of NPOP is to deal with documentation like National standards, accreditation criteria for accrediting inspection and certification agencies, Accreditation procedure, inspection and certification procedures and was only formulated after approval from National Steering Committee (NSC).

(p. bhattacharyvaand g. chakraborty)

The standards made by NPOP have been developed under guidelines of international organic production standards such as CODEX and IFOAM. The NPOP standards for production and accreditation system have been recognized by European Commission and Switzerland as equivalent to their country standards. Similarly, USDA has recognized NPOP conformity assessment procedures of accreditation as equivalent to that of US. With these recognitions, Indian organic products duly certified by the accredited certification bodies of India are accepted by the importing countries. 


\section{Growing sector outlook}

India had 42,000ha under certified organic farming in 2003-04 then in 2006-07 it grew to 5, 38,000 further in 2007-08 it increased to 8,65,000 and in march 2010 India pulled more than 4.48 million ha area under the organic certification process out of which 1.08 million ha was cultivated area and rest 3.4 million ha was under harvest collection area(Dr AK yadav certification and inspection rule) The state Madhya Pradesh ranks $1^{\text {st }}$ in area under organic farming with (1.1mhaor) constituting about 52\% then Maharashtra with 0.96 mhaor $33.6 \%$ followed by Orissa $(0.67$ mhaor $9.75 \%)$ and Uttrakhand and Sikkimare declared as organic states . India due to its diversity in agro climate can grow almost all the crop throughout the year in different parts of the country (table-1)

\section{Market section}

In 2004India produced 3, 96,997MTcertified organic product and in 2009-10 produced 1,624,339 MT certified organic product in which 10,887 MT cotton was produce alone making India the largest producer of organic cotton there are many other various type of organic product from in India in market namelyTea, coffee, cardamom, Spices( ginger, turmeric, chillies and cumin), Cereals (wheat, rice, jowar, and bajra),Pulses(pigeon pea, chickpea, green gram, red gram, and black gram), Oilseeds (groundnut, castor, mustard and sesame,) Fruits (banana, sapota, custard apple and papaya) Vegetables(tomato, brinjal, and other leafy vegetables), honey ,cotton and sugarcane especially for jaggery (GOI, 2001).

\section{Domesticmarket}

Organic farming in India is done basically with export intension very less products are circulated in the domestic market; such a high price of organic product makes it unstable in the domestic market to stand by the conventional products which are availablerelatively at cheaper rate(table-2).

Although domestic market has been suffering from some major disadvantages but its growth had never stopped it kept increasing in a slow pace

\begin{tabular}{|l|l|l|}
\hline Product & Organic (Price Rs./kg) & Conventional (Price Rs./kg) \\
\hline Rice & $32-110$ & $15-60$ \\
\hline Wheat & $35-40$ & $15-25$ \\
\hline Coffee & $475-1000$ & $350-500$ \\
\hline Tea & $450-1300$ & $250-500$ \\
\hline Spices & $400-1500$ & $250-800$ \\
\hline Pulses & $50-75$ & $25-40$ \\
\hline Fruits & $80-100$ & $20-100$ \\
\hline
\end{tabular}

Table 2: price comparison between conventional and organic productSource:Org-Marg,2002, market and opportunity for Indian organic product by Salvador V.garibay and katkejyoti

\section{Indian consumer}

Indian consumer are divided into 3 major classes depending upon their interest in the organic product $1^{\text {st }}$ upper class consumer $2^{\text {nd }}$ upper-middle class and $3^{\text {rd }}$ lower-middle class, a survey was conducted to know the view of the exporters and the traders about these classes 90percent of the respondent believed upper class consumers to be interested and only 10percent for upper-middle class and 0percent for lower class. The various demand of organic product in Indian consumer are given below (Fig-6)

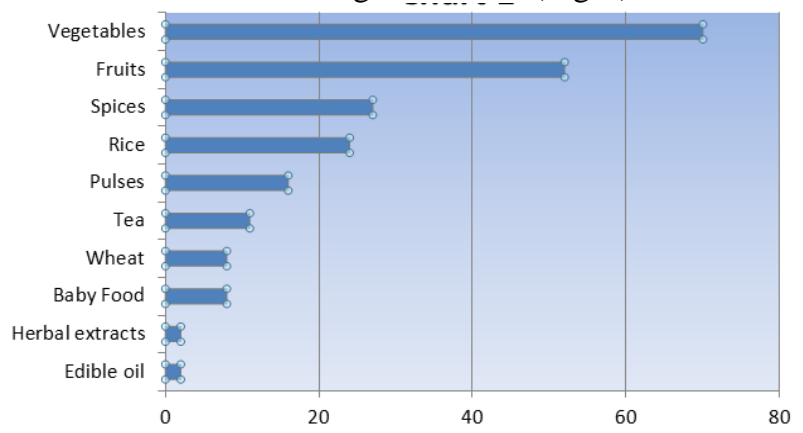

FiG 6: The demand of product in domestic marketSource: market and opportunity for Indian organic product by Salvador V.garibay and katkejyoti 


\section{Distribution pattern}

total outlet is 2,500 concentrated mainly within metropolitan cities like Delhi, Bangalore, Chennai, Hyderabad and are sold through either wholesaler/trader, supermarkets, own organic food stall etc (Fig-7). The reason for the purchasing is purely due to the health consciousness, the purchase ratio of organic to conventional is $1: 10$ and the sale of organic product in the domestic market is less than 7percent(salvadorv.garibay and katkejyoti)

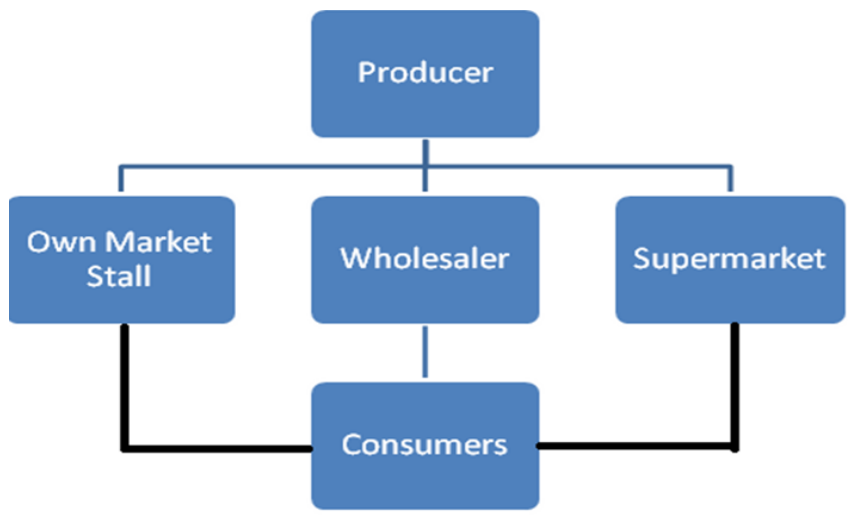

Fig7: chain of the market Source: market and opportunity for Indian organic product by Salvador V.garibay and katkejyoti

\section{Non-Government Organizations (NGO's)}

NGO's play a very vital role in the organic farming and market as they are the one directly linked with the farmers, exporters and traders, they act as the active promoter of the organic agriculture by helping farmers to understand the difference between the conventional and organic farming ,there impacts and help them in taking initiative in marketing. The promotion of organic production involves various steps

- Organizing the farmers;

- Educating them on the benefits of organic farming vs. conventional farming;

- Providing training to farmers in terms of:

o Maintaining proper documentation for certification

o Training in production practices as per certification requirements;

- Providing technical assistance;

- Providing organic seeds and inputs;

- Funding in rare cases;

- Organizing the export of the products through exporters.

Source: (salvadorv.garibay and katkejyoti)

\section{Organic Certification}

Organic certification is a process in which the producer / traders are certified to sell their products especially on the export level. There are certifying agencies which certify a product by regular inspection and make sure that the product getting label is produced under the given standardsfor at least 3 years (conversion period)(table 3), detail record of the production and sale should be maintained by producer/trader and should be submitted at time of inspection.

Certification makes clear distinction between organic and no organic product prevents any kind of fraud. The accreditation agencies in India approved by central government's ministry of commerce (MoC) are

Agricultural and processed food and export development authority (APEDA),

Coffee Board, Spice Board, Tea Board,

Coconut Development Board

And Cocoa \&Cashew nut Board.

The individual certifying body have their logo which work as brand among the customer and the producers, various certified bodies in India are

INDOCERT (based in India, office in Aluva, Kerala),

IMO India Pvt. Ltd. - Institute for Market ecology (based in Switzerland, office in Bangalore),

LACON GmbH (based in Germany, office in Aluva, Kerala),

SGS India Pvt. Ltd. (based in Switzerland, offices in Delhi and other cities)

ECOCERT International (based in France and Germany, branch office in Aurangabad

SKAL International (based in the Netherlands, branch office in Mumbai). 


\begin{tabular}{|l|l|l|}
\hline Category & Details & Fees (Rs) \\
\hline Small farmers and cooperatives & Travel and inspection & $12000 /$ day \\
& Report preparation & 5000 flat fee \\
& Certification & $5000 /$ certificate \\
\hline Estate manufacturers and & Travel and inspection & $19200 /$ day \\
exporters & Report preparation & 5000 flat fee \\
& Certification & $5000 /$ certificate \\
\hline Large and medium-sized & Travel and inspection & $16800 /$ day \\
processors & Report preparation & 5000 flat fee \\
& Certification & $5000 /$ certificate \\
\hline
\end{tabular}

Table 3: The cost of certification depending upon the holding of lands

Source: market and opportunity for Indian organic product by Salvador V.garibay and katkejyoti

There are many types of companies involved in producing organic product these companies are still young, low experienced and highly fragmented, trying to establish themselves in the market. In these successive years Fab India, Pristine Organics Pvt. Ltd., Organic Packaged Food India and Organic India Pvt have been able to earn good name in market. Ltd.Fab India is an Indian chain store since 2004, dealing with the retailing of garments, furnishings, fabrics, ethnic products etc. It works with it farmers towards the certification of their product and green seal, sign of organic is easily identified by consumers.

\section{Export market}

India's is very active in the export field of organic products producers and exporters know that there is a huge demand for the organic product in developed countries products available in export are mainly tea, spices ,rice, wheat ,coffee ,pulses ,fruits \& vegetables(table-4). During the year 2009-10, India exported 175 products under 21 categories for a volume of 58,500 Metric Tons (MT) for a value of $\$ 112$ million. The channels through which these products are exported are by the companies except for the Tea they are directly dealt by the state. The countries to which they are exported are as follows

- Europe: Netherlands, United Kingdom, Germany, Belgium, Sweden, Switzerland, France, Italy, Spain;

- Americas: USA, Canada;

- Middle East: Saudi Arabia, UAE;

- Asia: Japan, Singapore;

- Australia;

- Africa: South Africa.

\begin{tabular}{|l|c|}
\hline organic product & Production \\
\hline Basmati Rice & $5250 \mathrm{MT}$ \\
\hline Honey & $2692 \mathrm{MT}$ \\
\hline Teas & $2,727 \mathrm{MT}$ \\
\hline Dry fruits & $1,922 \mathrm{MT}$ \\
\hline processed food & $1,834 \mathrm{MT}$ \\
\hline Sesame & $1,396 \mathrm{MT}$ \\
\hline
\end{tabular}

Table 4: Major organic product produced during 2009-10

Source: market and opportunity for Indian organic product by Salvador V.garibay and katkejyoti

Major hindrance in export and possible solution

1. High price expectation —-Realistic price should be tagged

2. Low consistency of product — higher quality standard and improved post-harvest technique

3. Slow shipment — Duty port must reduce time and better infrastructure guaranteed at the arrival of goods

4. Complicate paper work $\longrightarrow$ develop fast track system for export

5. Mode of payment too slow— banks should raise their standards

6. Lack of awareness — promotional activities and internet portal access to information related to organic sector

7. Poor customer service — must take client follow ups \& traders must accomplish what they promise. 
The achievement of India in the area of Organic Food Production

1. Development of NPOP (National Production for Organic Production) document by APEDA under Ministry of Commerce. It includes all the internationally accepted Norms and Standards for organic agriculture and organic animal husbandry.

Indian brand -India Organic Logo

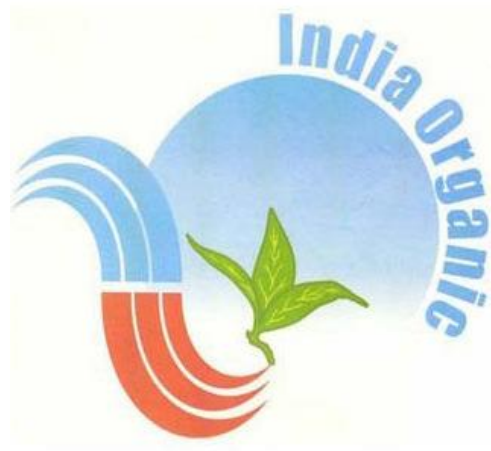

20 Accredited Certification Agencies (ISO-17011)

2. Introduction of the group certification for the small and marginal land holder's farmers

3. "National project on organic farming" launched by the department of agriculture and Cooperation in (2005).

Technology mission on horticulture" by MOA

4. FAO-DAC project on development of technical capacity base on the promotion of organic agriculture.

The NPOP standards have been recognised by European Union and USDA.

III. Discussion And Recommendation

If we compare our whole organic system with the other leading countries (EU or USA)we will find that there system is more integrated with a strategic vision, they are more stable, government is more involved, new initiatives are taken and farmers are encouraged to go organic due to reliable and feasible policies. In India we lack such comprehensive strategies which could serve as an instrument to achieve multiple policy goals (agriculture, environment and trade). List comparison between India and other countries are listed below(table-6)

Table 6: comparison between India and other countries

\begin{tabular}{|c|c|c|c|}
\hline Category & INDIA & EUROPEAN UNION & UNITED STATES \\
\hline $\begin{array}{l}\text { Organic action } \\
\text { plan }\end{array}$ & Absent & Present & Present \\
\hline $\begin{array}{l}\text { Government } \\
\text { aids }\end{array}$ & $\begin{array}{l}\text { NO subsidies or incentives } \\
\text { are } \\
\text { provided to organic farmers }\end{array}$ & $\begin{array}{l}\text { Area payment in form of } \\
\text { conversion area payment } \\
\text { or maintenance payment } \\
\text { or both are given }\end{array}$ & $\begin{array}{l}\text { subsidies during } \\
\text { conversion period is } \\
\text { given provided by govt } \\
\text { and state support is } \\
\text { also there in some } \\
\text { through EQIP }\end{array}$ \\
\hline $\begin{array}{l}\text { Inspection cost } \\
\text { support }\end{array}$ & ABSENT & PRESENT & PRESENT \\
\hline $\begin{array}{l}\text { Vocational/ } \\
\text { training } \\
\text { program }\end{array}$ & Less active & $\begin{array}{l}\text { Highly Active / } \\
\text { Frequent }\end{array}$ & $\begin{array}{l}\text { Highly Active/ } \\
\text { Frequent }\end{array}$ \\
\hline $\begin{array}{l}\text { global } \\
\text { awareness } \\
\text { among farmers }\end{array}$ & LOW & HIGH & HIGH \\
\hline $\begin{array}{l}\text { Initial } \\
\text { marketing } \\
\text { assistance } \\
\text { /support }\end{array}$ & $\begin{array}{l}\text { ABSENT } \\
\text { (though few NGO's have } \\
\text { taken an } \\
\text { effort to do so in few states) }\end{array}$ & $\begin{array}{l}\text { PRESENT } \\
\text { (the support is provided } \\
\text { through GO'S \&NGO'S) }\end{array}$ & $\begin{array}{l}\text { PRESENT } \\
\text { (the support is } \\
\text { provided through GO'S } \\
\text { \& NGO's) }\end{array}$ \\
\hline
\end{tabular}




\begin{tabular}{|l|l|l|c|}
\hline $\begin{array}{l}\text { Awareness } \\
\text { among } \\
\text { domestic } \\
\text { Consumers }\end{array}$ & LOW & $\begin{array}{l}\text { HIGH } \\
\text { (Germany stands at } \\
\text { second largest country in } \\
\text { world's organic market) }\end{array}$ & $\begin{array}{l}\text { HIGH } \\
\text { (U.S.A is the leading } \\
\text { country in global } \\
\text { organic market) }\end{array}$ \\
\hline $\begin{array}{l}\text { domestic } \\
\text { market }\end{array}$ & Least Focused & HIGH \& ACTIVE & HIGH \&ACTIVE \\
\hline Export market & FAIR RATE & HIGH RATE & HIGH RATE \\
\hline $\begin{array}{l}\text { Government } \\
\text { involvement }\end{array}$ & LOW & HIGH & HIGH \\
\hline
\end{tabular}

According to the data one thing is clear that Indian organic agriculture is suffering from poor linkage between farmers and markets and absence of financial support from the governments.We can see that almost very successful country in organic is providing subsidies or maintenance fund and in some both are being provided which is a major drawback in India as there is no financial support from government, poor farmers have to bear the whole expense from conversion till certification on their own private and big land holders still coop up with it but India consist of largely small holder farmers creating major problem for them. Supplies do not match the demand which is another problem caused by lack of direct linkage between producer and customer either caused by the manipulation of the traders or confusion in consumer demand. An important role of the government in this direction is giving various supports to the producer and consumer associations to market the products. Supply chain of the organic product can't be avoided and processing industry in India is badly fragmented, not organised. Proper plan should be initiated by introducing new improved refined technologies better the processing more sustainable the product will be thus increasing the market value of Indian organic product both in domestic and export market (table-7).

\begin{tabular}{|c|c|c|}
\hline Category & Strategies & Targeted Areas \\
\hline GOVERNMENT & $\begin{array}{l}\text { 1.improve organic national rules and } \\
\text { regulation } \\
\text { 2.provide financial help and subsidies to } \\
\text { farmers } \\
\text { 3.measures to improve domestic and export } \\
\text { market } \\
\text { 4.support domestic market initiatives }\end{array}$ & $\begin{array}{l}\text { 1.increase govt. } \\
\text { involvement } \\
\text { 2.financial support to the } \\
\text { farmers } \\
\text { 3.encourage farmers } \\
\text { 4. unstable market } \\
\text { 5.extensive documentation }\end{array}$ \\
\hline Small farmers & $\begin{array}{l}\text { 1.organise small farmers and make them act } \\
\text { as an organisation which produce and market } \\
\text { there product } \\
\text { 2.training program for farmers teaching them } \\
\text { production, harvest, post-harvest techniques } \\
\text { and basic standard } \\
\text { 3.include farmers in the operative } \\
\text { organisation of whole chain }\end{array}$ & $\begin{array}{l}\text { 1.lack of proper } \\
\text { organization } \\
\text { 2.lack of funds during } \\
\text { conversion period and } \\
\text { certification } \\
\text { 3.lack of marketing } \\
\text { initiatives }\end{array}$ \\
\hline NGO's & $\begin{array}{l}\text { 1.training on organic production, basic } \\
\text { standards, documentation } \\
\text { and } \\
\text { certification procedures } \\
\text { 2.access to continuous organic market } \\
\text { information }\end{array}$ & $\begin{array}{l}\text { 1.lack of funds } \\
\text { 2.lack of proper } \\
\text { infrastructure } \\
\text { 3.not properly organised }\end{array}$ \\
\hline Traders & $\begin{array}{l}\text { 1. Training programs for traders in how to } \\
\text { promote and sell product in domestic and } \\
\text { export organic market } \\
\text { 2. Continuous information of the market and } \\
\text { direct contact with the possible buyers }\end{array}$ & $\begin{array}{l}\text { 1.lack of marketing } \\
\text { strategies and there } \\
\text { implementation } \\
\text { 2.lack of domestic and } \\
\text { export market knowledge }\end{array}$ \\
\hline Certification & $\begin{array}{l}\text { 1.Reduction in cost of certification } \\
\text { 2.International standardization and simplified } \\
\text { certification procedure and less } \\
\text { documentation }\end{array}$ & $\begin{array}{l}\text { 1. high certification price } \\
\text { 2.lack of national } \\
\text { accreditation and } \\
\text { certification }\end{array}$ \\
\hline
\end{tabular}




\begin{tabular}{|l|l|l|l|}
\hline & & $\begin{array}{l}\text { 1.raw materials not easily } \\
\text { found } \\
\text { 2.lack of knowledge in } \\
\text { processing field } \\
\text { 2.Training on basic standard, documentation, } \\
\text { processing methods, inspection and } \\
\text { certification }\end{array}$ & $\begin{array}{l}\text { 3. need of upgrade } \\
\text { technologies }\end{array}$ \\
\hline & $\begin{array}{l}\text { 1.Increase awareness through promotion of } \\
\text { organic product by traders, NGO'S,\&GO'S } \\
\text { 2.Communication of the benefits of organic } \\
\text { to health, environment \&biodiversity } \\
\text { 3.Formation of moderate price so that } \\
\text { organic product is accessible to larger area }\end{array}$ & $\begin{array}{l}\text { 1.lack of awareness about } \\
\text { the benefits of organic } \\
\text { product } \\
\text { 2. high price of the product }\end{array}$ & \\
Domestic consumer & & & \\
\hline
\end{tabular}

Table 7: strategies suggested in regard of the problem concerned areas

An appropriate strong National Organic policy is the main need of the current position which will give an important place to organic farming addressing the current issues and obstacle, financial support from government will lower down the financial burden from farmers and will indeed inspire other farmers to go organic. Establishing linkage between the farmers, traders and consumers, inspection and certification bodies will lead to the proper flow of the practical information fostering better understanding of the whole organic sector and its loopholes and will lead to the development of organic market both domestic and export.

India is a developing country, it has limited supply of resources and so has to balance its need according to the resource available ,therefore priorities are called for, list of requirements will always be there both urgent and non-urgent so the requirements are needed to be listed according to the priorities, area demanding major focus should be call first hence policies should be made in accordance to the current priorities of the country's organic agriculture so that it works in a mutually supportive way eradicating or mitigating the obstacle(Fig- 9). And the main area is funding for conversion period and certification should be provided to the farmers and moreover it will encourage more farmers to go organic

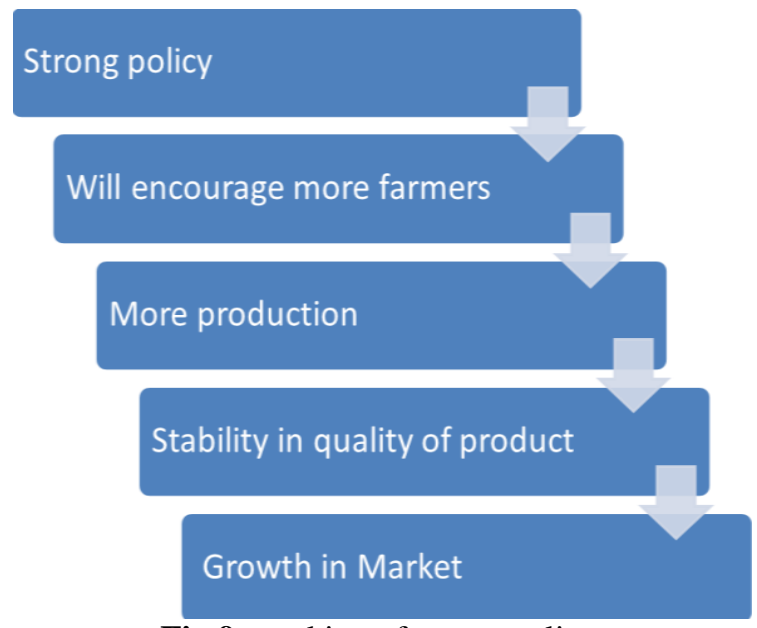

Fig 9: working of strong policy

A starting point for government is to give recognition and encouragement to the organic sector. This also includes the recognition of the relevance of organic sector organizations and the close cooperation between them and Governments (Fig-10). Governments should take an enabling and facilitating role rather than a controlling one setting the clear objectives Action plan, programmes and projects improving the overall policy covering a wide range of area from production, marketing, supply chain, training and research and training of the both civil servant and private sector should be the main area of concern. A fair, quick and efficient delivery system for such assistance should be made, perhaps by keeping the government bureaucracy at a distance 


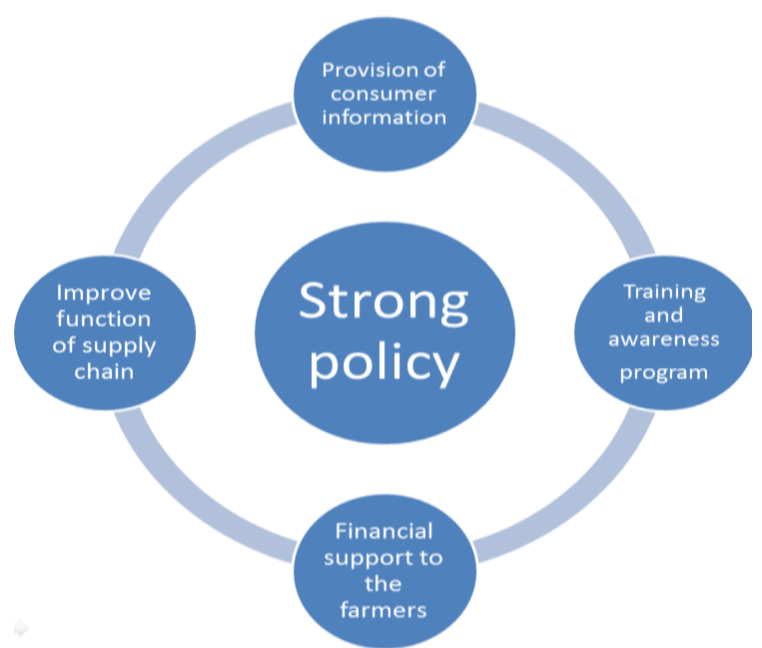

Fig 10: strong policy is based on 4 parameters

\section{RECOMMENDATION ON HOW A POLICY SHOULD BE FORMED}

\section{General policy}

1. The government needs to do a thorough and in-depth evaluation of the general picture of the organic sector policies, programs and plans, to understand how they affect the current organic sector

2. The objective should be clear before the action is taken and all the stakeholders should be involved in the policy development and development of the plans and programmes

3. General and organic agriculture should support each other to the greatest extent so that they promote the effective policy coherence, especially if organic as to be promoted as mainstreams

4. An action plan for the organic sector should be developed based on the analysis of the state of the sector, participatory consultations, a needs assessment and proper sequencing of the actions. The action plan should state measurable targets for the organic sector to help agencies and stakeholders focus their effort

5. One government ministry or agency should be assigned a leading role and organic desks should be established in other relevant ministries and agencies.

6. Recognize the diverse interests represented in the organic sector and ensure that all of them are considered properly as well as direct special attention to disadvantaged groups

7. A permanent body should be established for the consultations between the government and the private sector

8. Government should actively contribute to awareness rising for the organic agriculture on all levels

9. Data about the organic production and markets need to be collected over years, analysed and made available to the sector and policymakers

\section{Standards and regulation}

1. A national or regional standard for the organic production should be developed, through close cooperation between the private sector and government. It should be well adapted to the conditions in the country and mainly focus the domestic market

2. Producers, especially smallholders, should be supported to comply with standards, certification procedures and regulations. Special considerations should be taken for certification of smallholders. Training programmes for farmer groups to set up internal control systems should be supported.

3. Compulsory requirements for mandatory third-party certification should be avoided as they will not enable other alternatives to emerge. Other conformity assessment procedures, such as participatory guarantee systems, should be explored.

4. Before establishing regulations, Government should clarify the objectives. Governments regulating the sector should develop the regulations in close consultation with the sector and ensure that the regulation is enabling rather than controlling in nature.

\section{Markets}

1. Public procurement of organic products should be encouraged, including featuring organic food in important public events.

2. Consumer education and awareness should be actively promoted.

3. A common (national, regional or international) mark for organic products should be established and promoted. 
4. Domestic market development strategies should include measures for both the supply and demand side, including the role of imports.

5. The organization of farmers in regards to marketing, joint distribution and storage should be supported.

6.Market information systems should be established.

7. Export promotion activities should be supported, recognising the special nature of organic markets. Organic exporters should be encouraged to join forces to promote and market their products.

8. Organic products should be excluded from any mandatory sanitary treatments that are not permitted for organic products. Alternatives for fumigation should be supported.

\section{Production}

1. Direct support measures to producers need to be adapted to small farmers as well as to commercial operations.

2. Organic extension services need to be established and the staff trained. Organic extension should be developed and implemented in a participatory manner and have the farm and the farmer as the centre of attention.

3. Traditional knowledge about pest control treatments should be surveyed and brought into the extension service and disseminated in other ways.

4.A recycling of agriculture and food waste into organic farming systems should be promoted.

Government (or others) should establish basic controls of biological inputs such as pest control agents and organic fertilizers.

5.Seed breeding and seed testing should be oriented to organic production. Compulsory seed treatments should be waived for organic farmers and untreated seeds should be made available. Alternative seed treatments should be developed and promoted.

\section{Others}

1. Organic agriculture should be integrated into the curriculum for primary and secondary schools. Specialized institutions involved in training for organic agriculture should be supported. Higher education in organic agriculture should be developed.

2. Special research programmes should be established for organic research, and the sector should be involved in priority setting. Research and development (R\&D) in organic agriculture should be participatory, build on and integrate traditional knowledge (where relevant) and be based on the needs of the producers.

3. Governments and the private sector should participate in relevant international forums such as the Codex Alimentarius, IFOAM and the ITF.

4. Regional cooperation in marketing, standards, conformity assessment and R\&D should be promoted.

(Source:UNEP-UNCTAD Capacity Building Task Force on Trade, Environment and Development)

\section{Reference}

[1] Salvador V.GARIBAY and KATKE jyoti (feb 2003)Market opportunities and challenges for Indian organic product

[2] Willer, Helga and Kilcher, lukas(Eds) (2011)The World of Organic Agriculture Statistics and Emerging Trends (201

[3] P. BHATTACHARYVA and G. CHAKRABORTY (Dec 2005) National Centre of Organic Farming Ghaziabad

[4] Current Status of Organic Farming in India countries

[5] A.K Yadav (2002) certification and inspection systems in organic farming in India

[6] Renee Johnson (2008) CRS Report for the congress, organic agriculture in US: program and policy issues

[7] Matthias Stolze, Nicolas Lampkin (2009) Policy for organic farming: rationale and concepts

[8] HeidrumMoschtitz, Matthias Stolze (2009) organic farming policy networks in Europe:content,actors and variation

[9] Seemapurushothamam,Sheetalpatil and Ierene Francis (2012) Impact of policies favouring organic inputs on small farms in Karnataka ,India a multicriteria approachMatthias Lehner (2010) policies to promote organic agriculture

[10] GunnarRundgren (2008) united narion conference on trade and development united nation environment program, UNEP-UNCTAD Capacity Building Task Force on Trade, Environment and Development. 